УДК 697.1

В.I. Дешко, д-р техн. наук, проф.

І.Ю. Білоус, асис.

Г.О. Гетманчук

Національний технічний університет України «Київський політехнічний інститут імені Ігоря Сікорського»

\title{
БАЗИ КЛІМАТОЛОГІЇ ДЛЯ ВИЗНАЧЕННЯ ЕНЕРГЕТИЧНИХ ХАРАКТЕРИСТИК БУДІВЕЛЬ
}

\begin{abstract}
У даній роботі проаналізовано різні кліматичні бази даних, які використовуються при визначенні енергетичної потреби будівель на опаленні. В залежності від задач, щңо вирішуються, потреба в опаленні може визначатися в річному (стаціонарні методи), в помісячному (квазістаціонарні методи) та погодинному (динамічні методи) розрізі, що, в свою чергу, потребує різних пакетів вихідних параметрів (у тому числі - кліматичних даних). У методиках, які широко застосовуються в Украӥні, основні кліматичні параметри, які використовуються для розрахунку енергопотреби є зовнішня температура $i$ сонячні теплонадходження. Авторами проведено аналіз наявних в Україні кліматологічних даних та міжнародних кліматичних файлів погоди IWEC, визначено відмінності баз даних та встановлено їх вплив на розрахунки значення енергопотреби за допомогою динамічної моделі 5R1C кімнати.
\end{abstract}

Ключові слова: енергопотреба, бази кліматології, IWEC, зовнішня температура повітря, сонячні теплонадходження.

Вступ

В Україні громадські будівлі та житлові будинки є значними споживачами теплової енергії. За даними [1] 44\% виробленої теплової енергії споживається житлово-комунальним сектором. При цьому на централізоване опалення припадає 42\%. Рівень енергоспоживання будівель залежить від ряду факторів, таких як огороджувальні конструкції, кліматичні умови тощо. Саме тому для забезпечення раціонального використання енергетичних ресурсів на опалення необхідний ефективний підхід щодо встановлення можливого потенціалу економії енергоресурсів. Існує значна різноманітність методик та програмних продуктів з розрахунку енергопотреби будівель в опаленні, які базуються на стаціонарних, квазістаціонарних та динамічних підходах. При розрахунку енергетичних характеристик будівель поширеними в Україні стаціонарними й квазістаціонарними методами використовуються кліматичні характеристики для відповідного регіону/обласного центру, а саме - середньомісячні показники зовнішньої температури, сонячні теплонадходження на горизонтальну та вертикальні поверхні [2-4].

В умовах ефективного використання енергоносіїв потреба в опаленні повинна розраховуватися 3 урахуванням погодинної зміни кліматичних характеристик. В Україні все ширшого застосування набувають динамічні моделі визначення енергетичних характеристик будівель, які потребують використання погодинних кліматичних даних. Нормативної погодинної кліматології в Україні не існує.

В рамках дослідницького проекту RP-1015 U.S. National Climatic Data Center були створені кліматичні файли типового року International Weather for Energy Calculations (IWEC) для ряду міст. Процедура отримання даних була заснована на виборі типового року протягом 18-річної послідовності погодних даних. Погодинні значення з файлу IWEC [5] включають в себе температуру сухого термометра, відносну вологість, швидкість та напрям вітру, барометричний тиск, пряму (виражена через direct normal) та розсіяну сонячну радіацію на горизонтальну поверхню (diffuse horizontal) тощо. Для території України створено кліматичні IWEC файли типового року для міст у вільному доступі (Києва і Одеси), що можуть бути використані як усереднена характеристика кожної з двох температурних зон. В IWEC 2 створено погодні файли для 41-го міста України, але вони є платним ресурсом, що обмежує їх використання. [6]

Існують програмні продукти, які дозволяють аналізувати динамічні характеристики будівлі і використовують вже створені деталізовані файли кліматології. Наприклад, програмний продукт EnergyPlus використовує кліматичний файл IWEC [7]. Використання IWEC в інших підходах, крім програмного продукту EnergyPlus, має складнощі, пов'язані з форматом представлення інформації. Для перерахунку сонячної активності потрібно використати положення сонця відносно горизонту протягом року та його зміни протягом доби. EnergyPlus використовує кілька методик розрахунку сонячних теплонадходжень на вертикальні поверхні. [8]

Наприклад, в Інтернет ресурсі [9], створеному в рамках проекту NASA "Atmospheric science data center", можна задати географічними координатами потрібний регіон та отримати середньомісячні значення прямої, розсіяної, повної сонячної радіації на горизонтальну поверхню, кількість безхмарних днів у місяці, значення азимуту і таке інше. Дані приведенні на даному сайті, є усередненими

(C) B.I. Дешко, І.Ю. Білоус, Г.О. Гетманчук, 2017 


\section{ISSN 1813-5420 (Print). Енергетика: економіка, технології, екологія. 2017. № 4}

характеристиками за останні 22 роки.

Крім деталізованих кліматичних даних файлів IWEC на платному Інтернет ресурсі [10] можна отримати деталізовані погодинні значення сонячної активності для типового року або фактичні дані вибраного року. Обмежений доступ до даних є головною перешкодою їх використання.

В залежності від задач, що вирішуються, можуть використовуватися відповідні інтервали усереднення кліматичних даних. Дана робота присвячена дослідженню відмінностей різних баз даних кліматології та визначенню їх впливу на енергопотребу будівлі.

Мета та завдання

Метою роботи є аналіз застосування різних нормативних кліматичних баз даних для розрахунку енергетичної потреби в опаленні.

Відповідно до поставленої мети мають бути вирішені такі завдання:

1. Вибрати методики перерахунку кіліматичних даних сонячних теплонадходжень міжнародного файлу погоди IWEC на вертикальні поверхні;

2. Порівняння даних кліматології IWEC з діючою в Україні кліматологією;

3. Аналіз енергопотреби в опаленні отриманої за допомогою різних баз даних кліматології.

Матеріал та результати досліджень

Методика перерахунку сонячних теплонадходжень файлу ІWЕС на вертикальні поверхні для визначення енергопотреби

Територія України умовно позділяється на дві температурні зони. Кліматичні погодинні значення типового року IWEC створені для двох міст України: Київ (І кліматична зона) та Одеса (II кліматична зона). [4] Основна частина України відноситься до першої температурної зони.

При розрахунку енергопотреби за діючими в Україні методиками, серед кліматичних показників ураховується зовнішня температура повітря та сонячні теплонадходження на вертикальні та горизонтальні поверхні. Як згадувалось раніше, сонячні теплонадходження задані у файлі типового року через повну сонячну радіацію на горизонтальну поверхню, розсіяну сонячну радіацію на горизонтальну поверхню та прямі до нормалі променя. Існує велика кількість методик перерахунку даних сонячних показників теплонадходжень на сумарні теплонадходження на вертикальні поверхні відповідних орієнтацій. [11]

Програмні продукти, які використовують кліматичні дані типового року IWEC (наприклад, EnergyPlus), містять вбудовані методики перерахунку від спрощених до деталізованих. В Україні набув чинності спрощений погодинний динамічний метод розрахунку на базі європейського стандарту EN 13790 [12], який враховує у своїх розрахунках сумарні сонячні теплонадходження в зону кімнати. В роботі використана методика перерахунку сонячних теплонадходжень в зону кімнати за підходами, запропонованими в працях [11].

Схилення Сонця в певний день визначається за формулою:

$$
\delta=23,45 \sin \left(360 \frac{284+n}{365}\right),
$$

де n - порядковий номер дня, відрахований від 1 січня.

Кількість теплоти, яка надходить на вертикальні поверхні огородження, залежить від розташування в певній місцевості на широті $\varphi$ (для Києва 50²7', для Одеси $46^{\circ} 28^{\prime}$ ).

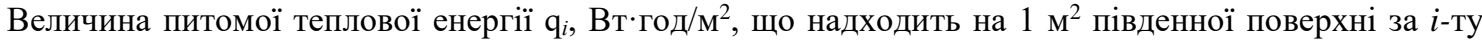
годину, визначається за формулою:

$$
q_{i}=H_{B} \frac{\cos (\varphi-s) \cos \delta \cos \omega+\sin (\varphi-s) \sin \delta}{\cos \varphi \cos \delta \cos \omega+\sin \varphi \sin \delta}+H_{D}=H_{B} \cdot R_{B}+H_{D},
$$

де $\mathrm{H}_{\mathrm{B}}$ i $\mathrm{H}_{\mathrm{D}}, \mathrm{BT} / \mathrm{M}^{2}$ - питомі теплові потоки прямого та розсіяного сонячного випромінювання, що падає на горизонтальну поверхню, на широті населеного пункту при безхмарному небі;

$\mathrm{R}_{\mathrm{B}}$ - коефіцієнт перерахунку прямої сонячної радіації на похилу поверхню з південною орієнтацією;

$\mathrm{s}-$ кут нахилу поверхні до горизонту $\left(\mathrm{s}=90^{\circ}\right)$.

При розрахунках за формулою (2) треба враховувати лише значення, які задовольняють умовам:

$$
\omega<90^{0} ; \omega<\omega_{C(3)}=\arccos (-\operatorname{tg}(\varphi-s) \cdot \operatorname{tg} \delta) ; R_{B}>0,
$$

де $\omega_{\mathrm{C}(3) .-}$ годинний кут сходу (заходу) сонця на похилу поверхню.

У розрахунках прийнято, що на північну поверхню потрапляє лише розсіяна сонячна радіація. В даній методиці розрахунку хмарність не врахована.

Тепловий потік, що надходить в зону кімнати, визначається:

$$
Q_{\text {sol }}=q_{i} F_{6} k_{n p} k_{3 m}
$$


де $Q_{\text {sol }}$ - тепловий потік від сонця в зону кімнати, Вт;

$q_{i}$ - питомий тепловий потік, що надходить на вертикальну поверхню відповідної орієнтації, Вт/м²; $F_{6}$ - площа світлопрозорих елементів конструкцій, ${ }^{2}$;

$k_{n p}$ - коефіцієнт пропускання сонячної радіації;

$k_{\text {зm }}$ - коефіцієнт, що враховує наявність затіняючих елементів.

\section{Порівняння даних кліматології IWEC і діючої в Украӥні кліматологї}

За наведеною вище методикою перераховано погодинні значення сумарних сонячних теплонадходжень на вертикальні поверхні. Для порівняння в роботі наведено крайні випадки сонячних теплонадходжень для Пд та Пн орієнтації. Для порівняння кліматологій встановлено середньомісячні значення зовнішньої температури і сонячних теплонадходжень (на рис. 1) для двох міст України.

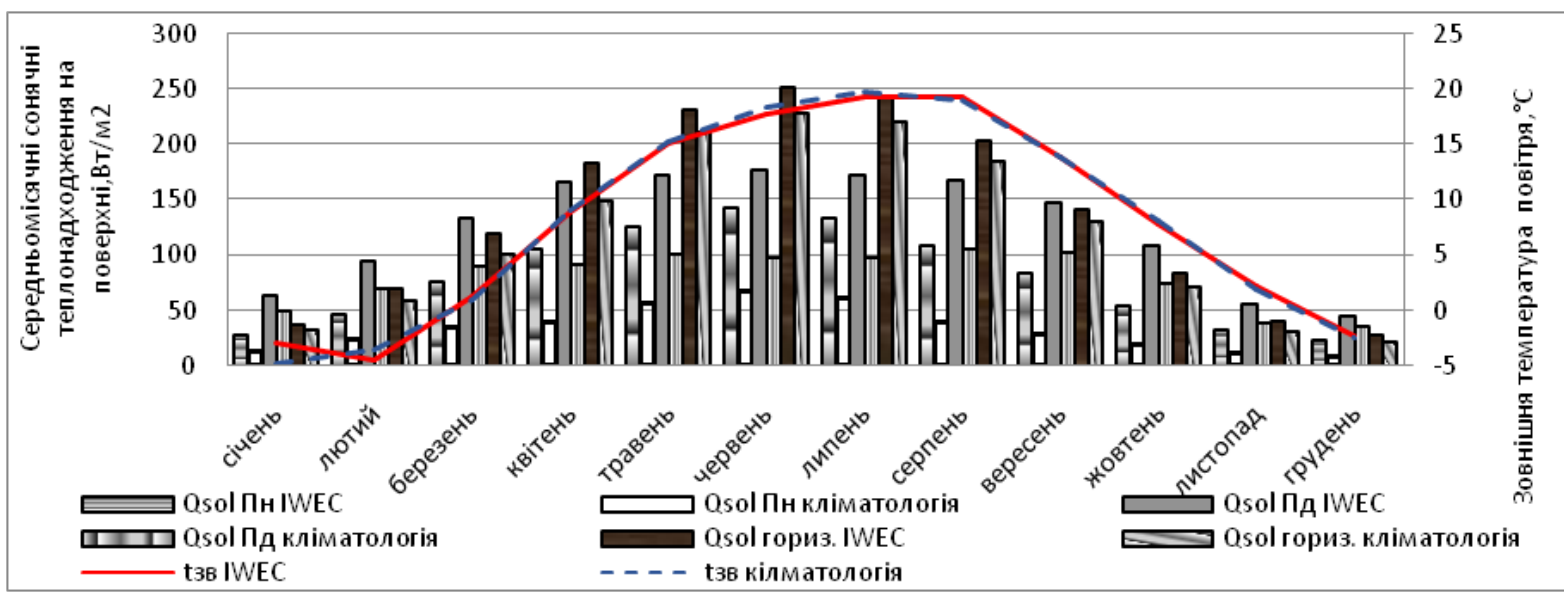

a)

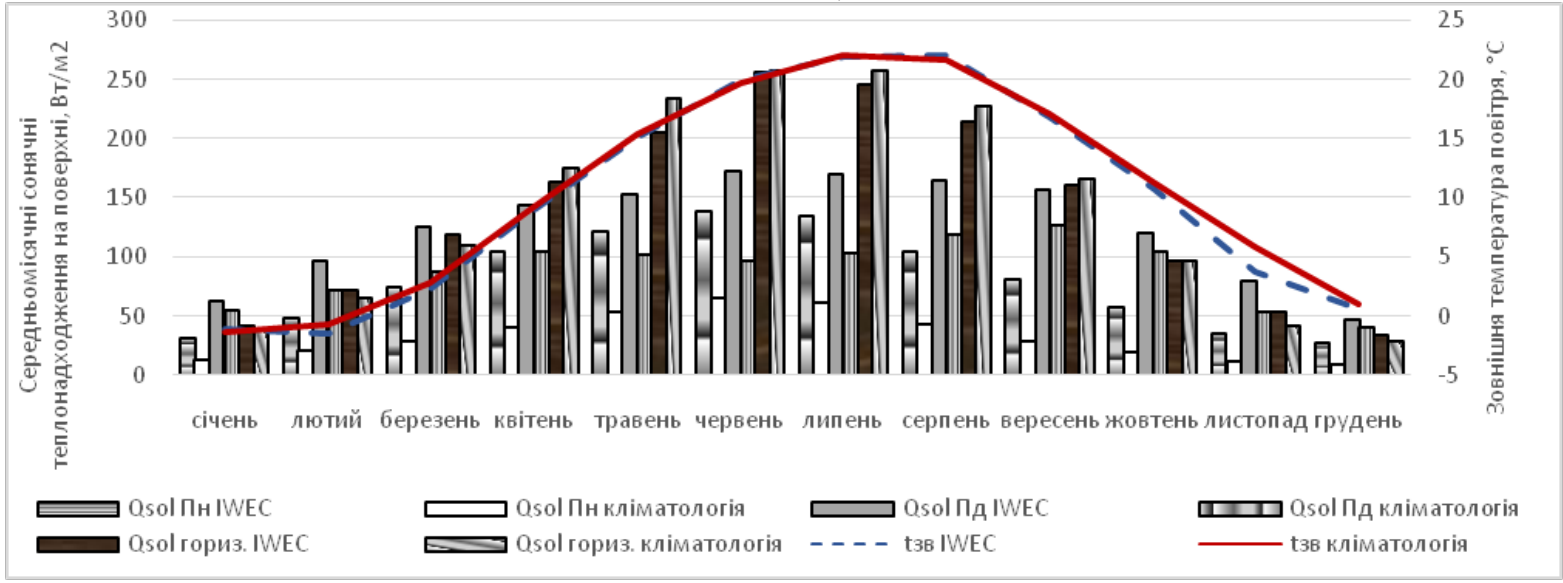

б)

Рисунок 1 - Середньомісячні кліматичні дані з нормативних документів України та Міжнародного погодного файлу для м.Києва (а) та м.Одеси (б)

Зовнішня температура повітря за двома кліматологічними базами майже не відрізняється. Сонячні теплонадходження суттєво відрізняються від прийнятих в Україні величин. Відмінність становить близько $40 \%$ в зимовий період та $30 \%$ в літній для Києва. Для Одеси дана розбіжність становить до 50\%. Сонячні теплонаходження на горизонтальну поверхню відрізняються на 5-10\%.

Для перехресної перевірки правильності методики перерахунку сонячних теплонадходжень на вертикальні поверхні було використано один найбільш деталізованих та прогресивних програмних продуктів EnergyPlus. В створеній моделі на базі EnergyPlus використано деталізовану методику розрахунку сонячних теплонадходжень "Full interior and exterior with reflection", що враховує відбивання від поверхонь та грунту та інші не менш вагомі фактори. Середньомісячні значення, отримані за класичною методикою розрахунку Даффі [11], яка наведена вище, та результати розрахунку в програмному продукті EnergyPlus досить близькі, максимальна розбіжність результатів у зимовий період склала $8 \%$, у літній - до $15 \%$.

Проблеми викликані не лише відмінністю вихідних кліматичних даних, але й неможливістю використання наведених кліматичних даних в Будівельній кліматології України [4] при динамічному 


\section{ISSN 1813-5420 (Print). Енергетика: економіка, технології, екологія. 2017. № 4}

погодинному розрахунку енергопотреби в опаленні. На рис. 2 наведено погодинну змінну сонячних теплонадходжень на горизонтальну поверхню та зовнішню температуру повітря для двох міст України

Врахування зміни кліматичних факторів протягом доби дозволяє уникнути перетопів у періоди максимальної сонячної активності в зимові періоди та забезпечити комфортну температуру в літній період.

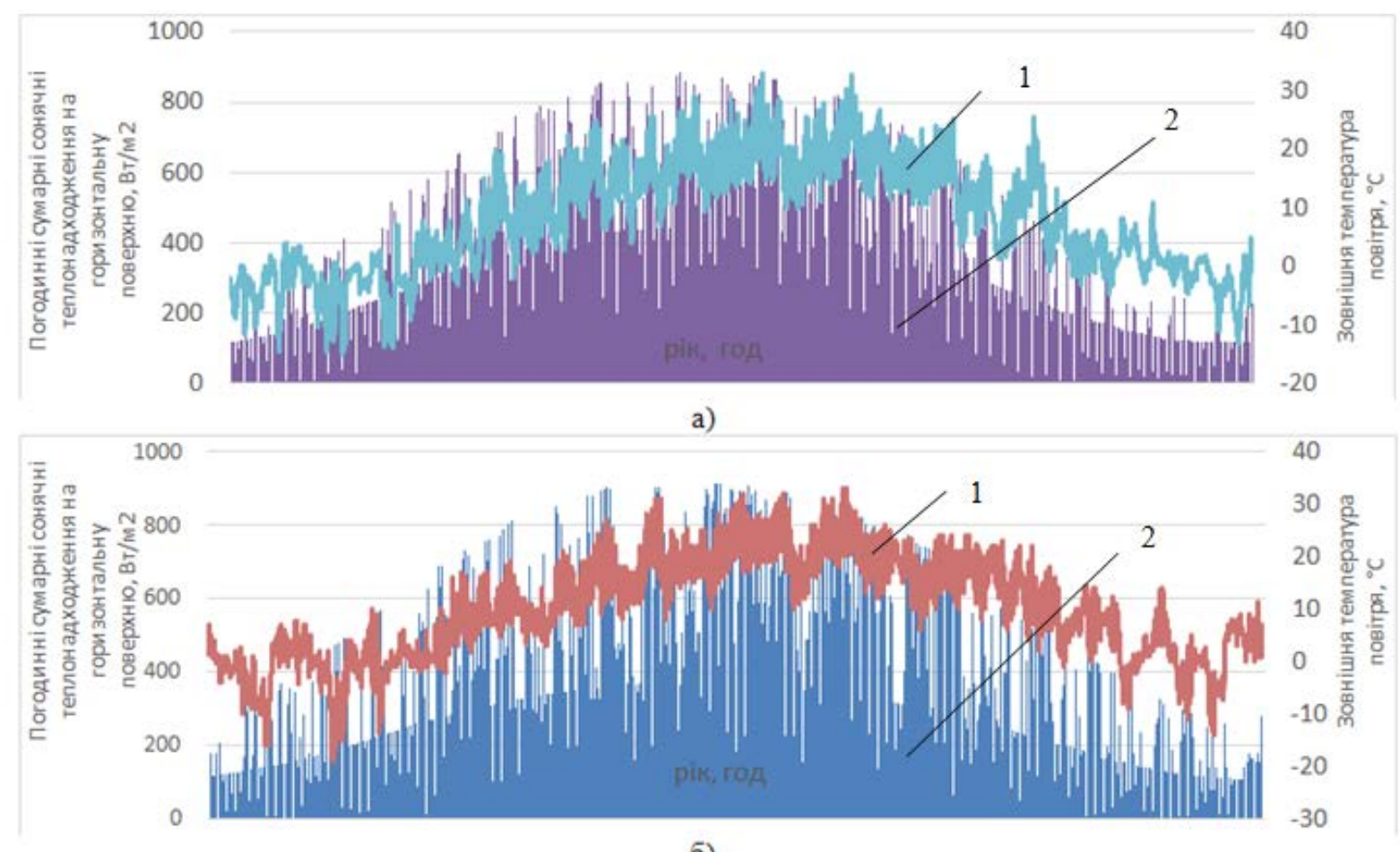

б)

1 - зовнішня температура повітря; 2 - сонячні теплонадодження на горизонтальну поверхню

Рисунок 2 - Погодинна зміна сонячних теплонадходжень на горизонтальну поверхню (2) та зовнішньої температури повітря (2) для м.Києва (а) та м.Одеси (б) за кліматичним файлом IWEC

Об'єкт дослідження кімната - будівлі масової забудови 1970 -х років. Розміри кімнати $5,5 \times 6,1$ м, висота приміщення 3,2 м. Кімната має одну зовнішню стіну $(5,5 \times 3,2$ м) з вікном $(5 \times 2$ м). Зовнішня стіна має термічним опір $0,8 \mathrm{~m}^{20} \mathrm{C} / \mathrm{B}$ (основний шар - цегляна кладка в одну цеглину). Вікно 3 подвійним заскленням у дерев'яних спарених плетіннях. Внутрішні стіни - цегляна кладка в пів-цеглини. Перекриття над опалювальними приміщеннями залізобетонні -20 см. Вентиляція - природна. Кратність повітрообміну 1 го $\mathcal{z}^{-1}$. Будівля знаходиться в м. Одеса. Проектна внутрішня температура повітря $18^{\circ} \mathrm{C}$. Система опалення - повітряна. Коефіцієнт пропускання сонячних теплонадходжень світлопрозорих конструкцій в зону кімнати становить 0,56 . Кімната має південну орієнтацію.

За допомогою динамічної моделі 5R1C, що була створена на базі європейських стандартів EN 13790 та EN 13786 [12, 13], проведено погодинний розрахунок енергопотреби на опалення за середньомісячними даними кліматології, що діє в Україні та за годинними та середньомісячними даними за кліматичним файлом IWEC для м. Одеса (рис.3).

В роботі використано динамічну модель $5 \mathrm{R} 1 \mathrm{C}$ для визначення енергопотреби на опалення. При погодинному розрахунку за середньомісячними даними $є$ плавні переходи, пов'язані з тепло-інерційними особливостями непрозорих огороджень. При погодинному розрахунку за середньомісячними даними розглянутих кліматологій розбіжність річної енергопотреби складає 300 кВт·год/рік або $10 \%$. Якщо порівнювати результати розрахунку річної енергопотреби при погодинному розрахунку за погодиними i середньомісячними даними погодного файлу IWEC, енергопотреба в річному розрізі майже однакова (рис.3). 
ISSN 1813-5420 (Print). Енергетика: економіка, технології, екологія. 2017. № 4

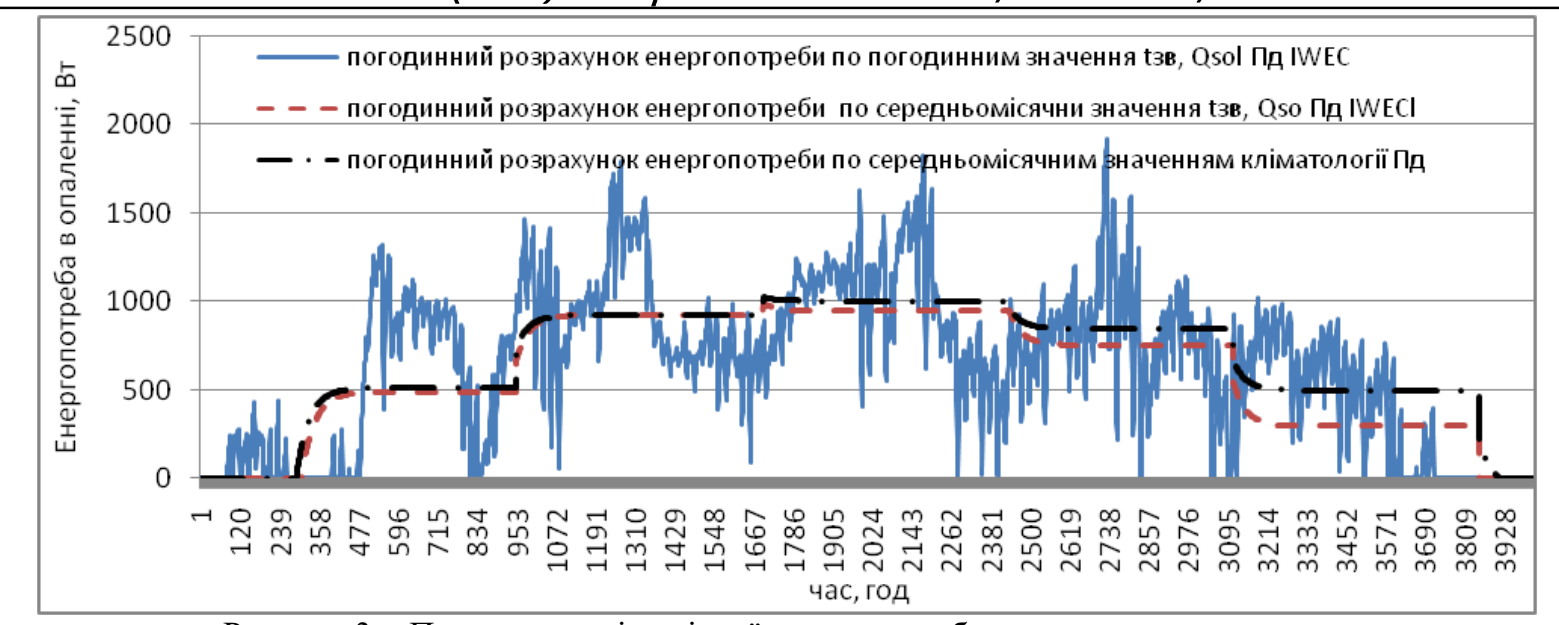

Рисунок 3 - Погодинна зміна річної енергопотреби на опалення по погодинним та середньомісчним значенням файлу IWEC [5] та середньомісячним значенням будівельної кліматології кліматології [4] для кімнати орієнтованої на Пд

\section{Висновки}

У роботі проведено аналіз та співставлення нормативних кліматичних даних,що діють в Україні та міжнародного погодного файлу IWEC при їх використанні для визначення потреби на опалення. Кліматичні файли IWEC створені для двох міст України: Київ (І кліматична зона) та Одеса (II кліматична зона), що є доволі усередненою характеристикою кожної з двох температурних зон. В нормативних кліматологічних даних, що діють в Україні, наведено середньомісячні значення зовнішньої температури повітря та сонячних теплонадходжень на вертикальні та горизонтальну поверхні, що є достатнім при стаціонарному та квазістаціонарному методі розрахунку. При розрахунку енергетичної потреби будівель на опалення та/або охолодження динамічними методами потрібні погодинні кліматичні значення. Міжнародні кліматичні файли погоди для розглянутих міст України майже не відрізняються за середньомісячними значеннями зовнішньої температури від нормативної кліматології України. Сонячні теплонадходження, які наведені в файлі IWEC, не можуть одразу бути використані для порівняння кліматичних баз даних або розрахунку енергопотреби будівель, тому в роботі наведена методика перерахунку сонячних теплонадходжень. Сонячні теплонадходження на вертикальні та горизонтальні поверхні за даними файлу IWEC суттєво відрізняються від діючої в Україні кліматології. Середньомісячна відмінність сонячної активності на вертикальні поверхні становить близько $40 \%$, на горизонтальні - до $10 \%$.

У роботі використано динамічну модель 5R1C для визначення енергопотреби на опалення при використанні різних кліматологій для кімнати, орієнтованої на Пд, розташованої у м.Одеса. При погодинному розрахунку за середньомісячними даними розглянутих кліматологій розбіжність річної енергопотреби становить 300 кВт.год/рік або 10\%. Подібні відмінності за рахунок використання кліматичних баз даних потрібно враховувати при порівнянні різних методик розрахунку енергопотреби.

При динамічному моделюванні на базі програмних продуктів, у більшості випадків використовуються деталізовані кліматичні дані з міжнародних баз даних відповідного формату (наприклад IWEC), що обмежує використання діючої в Україні кліматології.

Розвитком подальших досліджень $є$ розробка методики перерахунку середньомісячних кліматичних даних на погодинні, враховуючи особливості розподілу кліматичних значень сонячних теплонадходжень і температури повітря протягом доби.

Дослідження були проведені за підтримки Міністерства освіти і науки України, в рамках проекту "Управління енергоспоживанням об'єктів комунальної енергетики" (номер державної реєстрації 0117U000469).

\section{Список використаної літератури}

1. Полуянов В. П. Перспективы развития централизованного теплоснабжения в Украине в контексте государственно-частного партнерства / Полуянов В. П., Кравченко Р. С. // БІЗНЕСІНФОРМ, 2012. - №5. - С. 109-112.

2. ДСТУ_Н Б А.2.2.5:2007. Проектування. Настанова з розроблення та складання енергетичного паспорта будинків при новому будівництві та реконструкції [Текст]. - Уведено вперше; чинний від 2008.07.01. - К. : Мінрегіонбуд України, 2008. - 44 с. 


\section{ISSN 1813-5420 (Print). Енергетика: економіка, технології, екологія. 2017. № 4}

3. ДСТУ Б А.2.2-12:2015. Енергетична ефективність будівель. Метод розрахунку енергоспоживання при опаленні, охолодженні, вентиляції, освітленні та гарячому водопостачанні [Текст]. - Уведений вперше; чинний від 2015.01.01. - К. Мінрегіонбуд України, 2016. - 205 с.

4. ДСТУ-НБ В.1.1-27:2010.Будівельна кілматологія. - К., 2011. - 127 с.

5. [Електроний ресурc]: https://energyplus.net/weather-location/europe_wmo_region_6/UKR.

6. [Електроний ресурc]: https://www.ashrae.org/resources--publications/bookstore/iwec2

7. [Електроний ресурс]: https://energyplus.net/

8. EnergyPlus: Creating a new-generation building energy simulation program. Crawley D.B., Lawrie L.K., Winkelmann F.C., Buhl W.F., Huang Y.J., Pedersen C.O., Strand R.K., Liesen R.J., Fisher D.E., Wittef M.J., Glazer J. Energy and Buildings. 2001. № 33. Pp. 319-331.

9. [Електроний ресурс]: https://eosweb.larc.nasa.gov/cgi-bin/sse/grid.cgi?email=tashkent@meta.ua

10. [Електроний ресурc]: http://www.meteonorm.com

11. W. Beckman, S. Klein, J. Duffy. Calculation of systems of solar heat supply. M.: Energoizdat, 1992.

12. EN 13790:2008. Energy performance of buildings - Calculation of energy use for space heating and cooling. - CEN. European Committee for Standardization, 2008. 53 p.

13. EN ISO 13786:2007. Thermal performance of building component - Dynamic thermal characteristics Calculation methods. — CEN. European Committee for Standardization, 2007. 27 p.

УДК 697.1

В.И. Дешко, д-р техн. наук, проф.

И.Ю. Белоус, асс.

А.А. Гетманчук

Национальный технический университет Украины

Национальный технический университет Украины «Киевский политехнический институт имени Игоря Сикорского» БАЗЫ КЛИМАТОГИИ ДЛЯ ОПРЕДЕЛЕНИЯ ЕНЕРГЕТИЧЕСКИХ ХАРАКТЕРИСТИК ЗДАНИЙ

В данной работе проанализированы различные климатические базы данных, используемые при определении энергетической потребности зданий на отоплении. В зависимости от решаемых задач, потребность в отоплении может определяться в годовом (стачионарные методы), в помесячном (квазистационарные методы) и почасовом (динамические) разрезе, что в свою очередь требует разных пакетов исходных параметров (один из них - это климатические данные). В методиках, иироко применяемых в Украине, основными климатическими параметрами, используемыми при расчете энергопотребности, являются внешняя температура и солнечные теплопоступления. Авторами проведен анализ действующих в Украине климатологических данных и международного климатического файлу погоды IWEC, определены различия баз данных и на примере комнаты установлено отличие рассчитанного значения энергопотребности с помощью динамической модели 5R1C по разным климатологиям.

Ключевые слова: энергопотребность, базы климатологии, IWEC, внешняя температура воздуха, солнечные теплопоступления.

V. Deshko, Dr. Eng. Sc., Prof.,

I. Bilous, TF

H. Hetmanchuk

National Technical University of Ukraine “Igor Sikorsky Kyiv Polytechnic Institute” BASES OF CLIMATIC FOR BUILDINGS ENERGY PERFORMANCE DETERMINATION

In this paper various climatic databases are used which are used in determining the energy requirement of buildings for heating. Depending on the tasks, the need for heating can be determined in the annual (stationary methods), in the monthly (quasi-stationary methods) and hourly (dynamic methods) section, which in turn requires a different package of output parameters (one of them is climatic data). In the techniques widely used in Ukraine, the main climatic parameters used in calculating energy demand are external temperature and solar heat consumption. The authors analyze the existing climatological data in Ukraine and the international climatic weather file of the IWEC, determine the differences between the databases and establish the difference in the calculated energy demand using the 5R1C dynamic model, for example.

Keywords: energy need, bases of climatology, IWEC, outside temperature, solar heat transfer.

\section{References}

1. Poluyanov V.P., Kravchenko R.S. (2012) Perspektivi razvitiya zentralizovanogo teplosnabgeniya v Ukraine $\mathrm{v}$ kontekste gosudarstvenno-chastnogo partnerstva [Prospects of the district heating development in Ukraine in the context of state-private partnership]. Biznesinform, 5, 109-112 (rus). 
2. DSTU N B A.2.2.5: 2007. Proektuvannya. Nastanova z rozroblennya ta skladannya enerhetychnoho pasporta budynkiv pry novomu budivnytstvi ta rekonstruktsiyi [Designing. Guidelines for the development and assembly of energy passports for buildings under new construction and reconstruction]. K.: Minrehionbud Ukrayiny, 2008. 44 p. (ukr)

3. DSTU B A.2.2-12:2015. Enerhetychna efektyvnist' budivel'. metod rozrakhunku enerhospozhyvannya pry opalenni, okholodzhenni, ventylyatsiyi, osvitlenni ta haryachomu vodopostachanni [Energy efficiency of buildings. Method of calculation of energy heating, cooling, ventilation, lighting and hot water]. K.: Minrehion Ukrayiny. 2015. 205 p. (ukr)

4. DSTU-N B V.1.1-27:2010. Budvel'na klimatolohiya [Construction climatology]. K.: Minrehion Ukrayiny. 2010. 127 p. (ukr)

5. [Electronic resource]: https://energyplus.net/weather-location/europe_wmo_region_6/UKR.

6. [Electronic resource]: https://www.ashrae.org/resources--publications/bookstore/iwec2

7. [Electronic resource]: https://energyplus.net/

8. EnergyPlus: Creating a new-generation building energy simulation program. Crawley D.B., Lawrie L.K., Winkelmann F.C., Buhl W.F., Huang Y.J., Pedersen C.O., Strand R.K., Liesen R.J., Fisher D.E., Wittef M.J., Glazer J. Energy and Buildings. 2001. № 33. Pp. 319-331.

9. [Electronic resource]: https://eosweb.larc.nasa.gov/cgi-bin/sse/grid.cgi?email=tashkent@meta.ua

10. [Electronic resource]: http://www.meteonorm.com

11. W. Beckman, S. Klein, J. Duffy. Calculation of systems of solar heat supply. M.: Energoizdat, 1992.

12. EN 13790:2008. Energy performance of buildings - Calculation of energy use for space heating and cooling. - CEN. European Committee for Standardization, 2008. 53 p.

13. EN ISO 13786:2007. Thermal performance of building component - Dynamic thermal characteristics Calculation methods. - CEN. European Committee for Standardization, 2007. 27 p.

Надійшла 13.11.2017

Received 13.11.2017

УДК 697.1

M.М. Шовкалюк, канд. техн. наук, доц., ORCID 0000-0002-1898-3493

C.В. Зіменко, магістр, ORCID 0000-0003-4151-0931

Національний технічний університет Украӥни «Київський політехнічний інститут імені Ігоря Сікорського»

\title{
АНАЛІЗ ТЕПЛОВТРАТ ЧЕРЕЗ ОГОРОДЖЕННЯ 3 УРАХУВАННЯМ РІЗНИХ МЕТОДІВ ОЦІНКИ ТЕПЛОЗАХИСНИХ ВЛАСТИВОСТЕЙ
}

\begin{abstract}
Метою роботи є дослідження теплових потоків та аналіз теплових втрат з опалювальних приміщень. У статті проаналізовано проблематику питання та взято до розгляду конкретний об'єкт дослідження, розглянуто його конструктивні особливості та конкретні теплопровідні включення за допомогою різних методик розрахунку. Розглянуті методики діючих сучасних стандартів України щодо розрахунку теплозахисних властивостей огороджувальних конструкцій будівлі з врахуванням теплових включень та без них. За результатами дослідження визначено відмінності між методиками, розраховано ключові параметри, визначено відмінності між підходами. Результатом дослідження є висновок щодо значного впливу теплових включень на загальний рівень теплозахисних властивостей огороджувальних конструкиій та важливість правильного вибору методики розрахунку з врахуванням існуючих даних про об'єкт. У висновках визначено, ще методика оцінки теплових втрат з врахуванням теплових включень дозволяє більш точно оцінити теплозахисні властивості ділянки дослідження.
\end{abstract}

Ключові слова: огороджувальні конструкції, тепловий захист, теплопровідні включення.

(C) М.М. Шовкалюк, С.В. Зіменко, 2017 